\title{
Pelatihan Pembuatan Nugget Jantung Pisang Kepada Ibu-Ibu PKK Kelurahan Sukorejo Kabupaten Lamongan Untuk Meningkatkan Pendapatan
}

\author{
Novi Darmayanti ${ }^{1}$, Isnaini Anniswati R ${ }^{2}$, Nurul Fauziyah ${ }^{3}$, Fitri Amelia Sari ${ }^{4}$ \\ 1,2,3 Dosen Akuntansi Fakultas Ekonomi Universitas Islam Darul Ulum Lamongan \\ ${ }^{4}$ Mahasiswa Akuntansi Fakultas Ekonomi Universitas Islam Darul Ulum Lamongan \\ Email: novismile_ub@yahoo.com
}

\begin{abstract}
ABSTRAK
Keberadaan jantung pisang saat ini di anggap sampah bagi masyarakat, padahal jika kita menelusuri jantung pisang memiliki manfaat yang luar biasa bagi kesehatan. Jantung pisang mengandung berbagai zat yang baik bagi kesehatan seperti flavonoid, protein, fosfor, mineral, kalsium, vitamin B1,vitamin C, kandungan serat yang cukup tinggi. Selain itu jantung pisang sangat aman di konsumsi bagi anda yang sedang menjalani program diet karena kandungan lemaknya sangat sedikit dan memberi rasa kenyang yang lebih lama. Kebanyakan masayarakat terutama ibu ibu rumah tangga menganggap remeh jantung pisang ini karena harganya yang sangat murah dan biasanya hanya di konsumsi oleh kalangan pedesaan. Jantung pisang berpotensi memiliki nilai jual yang tinggi apabila diolah secara baik dan benar serta dikemas secara menarik hingga menjadi suatu produk makanan. Metode pelaksanaan kegiatan percobaan dengan memanfaatkan dan mengolah jantung pisang menggunakan satu buah jantung pisang yang dicampur dengan bumbualami. Hasil pengabdian masyarakat ini adalah dengan adanya pengolahan nugget dari jantung pisang tersebut adalah (1) menjadi peluang usaha bagi masyarakat pedesaan untuk meningkatkan kesejahteraan ekonomi, (2) mengatasi permasalahan terkait limbah tanaman yang dapat mengotori dan mencemari lingkungan.
\end{abstract}

Kata Kunci: nugget, jantung pisang, limbah tanaman

\section{ABSTRACT}

The existence of banana hearts is currently considered rubbish for the community, even though if we explore banana hearts it has tremendous benefits for health. Banana heart contains various substances that are good for health such as flavonoids, protein, phosphorus, minerals, calcium, vitamin B1, vitamin C, a high fiber content. In addition, banana hearts are very safe for consumption for those of you who are undergoing a diet program because they contain very little fat and provide a longer feeling of fullness. Most people, especially housewives, underestimate this banana heart because it is very cheap and usually only consumed by rural people. Banana heart has the potential to have a high selling value if it is processed properly and properly and is attractively packaged to become a food product. The method of implementing the experimental activity was by utilizing and processing banana blossoms using one banana flower mixed with natural spices. The result of this community service is that the processing of nuggets from the banana heart is (1) becoming a business opportunity for rural communities to improve economic welfare, (2) overcoming problems related to plant waste that can pollute and pollute the environment.

Keywords: nuggets, banana heart, plant waste 


\section{PENDAHULUAN}

Di zaman yang serba modern ini orang lebih suka makan makanan cepat saji. Mulai dari anak-anak, remaja, dewasa, hingga ibu-ibu rumah tangga maupun yang berkarier, mereka cenderung lebih memilih sesuatu yang praktis, karena dengan kesibukannya. Tida tertinggal pula para mahasiswa yang mencari kemudahan dan kepraktisan, apalagi dengan jadwal kuliah yang cukup padat, tak heran menu makanan yang dipilih tak jauh dari makanan yang praktis. Bahan makanan yang memerlukan proses untuk dapat dikonsumsi seperti pengelupasan, pencucian dan pemasakan sekarang semakin ditingglkan. Di saat emakin populernya mie instan dan makanan kebarat-baratan, keberadaan jantung pisang seakan semakin tersingkirkan. Bahkan jantung pisang dianggap menu makanan kalangan menengah kebawah. Keberdaan jantung pisang yang semakin terlupakan, perlu dilihat sisi lain dari manfat jantung pisang jantung pisang mengandung berbagai manfaat jantung pisang. (Panji R,2012

Sebagai Negara agraris dimana mayoritas penduduknya bermata pencaharian sebagai petani menjadikan Indonesia sebagai salah satu negara produsen pisang yang penting di dunia, dengan beberapa daerah sentra produksi terdapat di pulau Sumatera, Jawa, Bali, dan NTB. Namun sebagian besar petani pisang ataupun produsen pisang tersebut hanya memanfaatkan hasil pohon pisang yang ada berupa bagian buah pisang dan tidak memanfaatkan bagian yang lain dari pohon pisang yakni jantung pisang atau bunga pisang (ontong gedang dalam istilah jawa). Padahal jantung pisang merupakan bagian penting dari pohon pisang yang semestinya dapat dioptimalkan penggunaanya sebagai makanan sehat yang dapat dikonsumsi. Karena jantung pisang mengandung vitamin-vitamin yang bermanfaat bagi kesehatan manusia seperti vitamin A, vitamin $B$, vitamin $\mathrm{C} 1$, selain itu jantung pisang juga mengandung energi, protein, karbohidrat, kalsium, fosfor dan lemak.

Selama ini jantung pisang memang sudah banyak dimanfaatkan untuk pembuatan beberapa makanan seperti abon jantung pisang, tumis jantung pisang dan lain-lain. Namun pada karya ini dibuat suatu inovasi makanan baru yang berbahan dasar dari jantung pisang yaitu nugget jantung pisang karena nugget merupakan jenis makanan praktis yang banyak digemari dan diminati oleh masyarakat modern sekarang. Selain untuk mengoptimalkan penggunaan jantung pisang sebagai sayuran yang sering dibuang karena dianggap limbah dan tidak bisa menghasilkan buah pisang lagi,pembuatan nugget jantung pisang juga untuk meningkatkan nilai jual jantung pisang di pasaran.

\section{Permasalahan yang Dihadapi}

1. Bagaimana cara mengolah limbah jantung pisang menjadi makanan yang bergizi dan berdaya ekonomis?

2. Bagaimana cara mengenalkan nugget jantung pisang sebagai makanan yang mengandung banyak manfaat kepada masyarakat?

\section{Tujuan yang Diharapkan}

Tujuan dibuatnya program pengabdian masyarakat ini adalah

1. Untuk melatih kemandirian berwirausaha, khususnya untuk ibu-ibu rumah tangga. Untuk menciptakan jiwa dan mental dalam berwirausaha.

2. Untuk melatih kemampuan bekerja sama dalam tim. Dapat meningkatkan sosialisasi dengan masyarakat luas.

3. Untuk melatih memanajemen dan memanfaatkan waktu, tenaga, dan biaya yang dikeluarkan. 
4. Untuk memenuhi kebutuhan makanan ringan yang enak, lezat serta dapat menyembuhkan penyakit kolestrol dan cocok untuk orang yang sedang diet.

\section{Manfaat yang Diharapkan}

Manfaat dari program pengabdian masyarakat ini adalah :

1. Masyarakat, terutama ibu-ibu rumah tangga diharapkan dapat mengolah limbah jantung pisang menjadi cemilan yang diminati oleh banyak kalangan. Dengan banyak manfaat, menciptakan cemilan yang lezat, enak, dan bergizi, karena jantung pisang mengandung vitamin-vitamin yang bermanfaat bagi kesehatan manusia seperti vitamin A, vitamin B, vitamin $\mathrm{C} 1$, selain itu jantung pisang juga mengandung energi, protein, karbohidrat, kalsium, fosfor dan lemak.

2. Masyarakat, terutama ibu-ibu rumah tangga diharapkan mendapatkan keuntungan finansial yang dapat meningkatkan tarif kesejahteraan hidup.Mengembangkan UKM (Usaha Kecil Menegah) yang ada di Indonesia.

\section{METODE PELAKSANAAN}

\section{Persiapan Bahan Baku, Peralatan dan Tempat Pemasaran}

Pada tahap ini, yang pertama kami mempersiapkan bahan bakuterlebih dahulu yang bahan utama dari produk kami yaitu jantung pisang. Selain bahan utama tersebut, kami juga mempersiapkan bahan-bahan pelengkap lainnya seperti bawang putih, bawang merah, merica, tepung terigu, tepung roti, garam, cabai dan lain-lain. Selain mempersiapkan bahan-bahan, kami juga mempersiapkan peralatan-peralatan untuk mendukung dalam pembuatan nugget jantung pisang yang terdiri daripenggorengan, kompor, gas, spatula, box, baskom, pisau, talenan dan masih banyak lagi. Untuk memasarkan produk, sebelum memasarkannya kami mempersiapkandan menentukan tempat terlebih dahulu, tempat yang paling strategis, ramai, dan mudah diketahui keberadaannya seperti dijalan-jalan, di dalam kampus atau diluar kampus, dan juga menyewa tempat.

\section{Uji Coba Pembuatan}

Pada tahap ini, kami melakukan uji coba pembuatan nugget jantung pisang.Tempat uji coba yaitu di rumah salah satu anggota kami.Uji coba pembuatan nugget jantung pisang kami lakukan selama tiga minggu agar kami dapat membuat dengan sebaik mungkinuntuk pembuatan nugget jantung pisang tersebut agar rasanya pas dan enak.dan kita juga menguji coba apakah jantung pisang itu dapat di konsumsi dan selama penelitian yang kami. 


\section{Cara Pembuatan nugget jantung pisang}

Cara Pembuatan nugget jantung pisang ini, sangat mudah dilakukan dan pada umumnya sama seperti pembuatan nugget lain yang sudah diketahui.

\section{BAHAN-BAHAN :}

Jantung pisang 3 buah

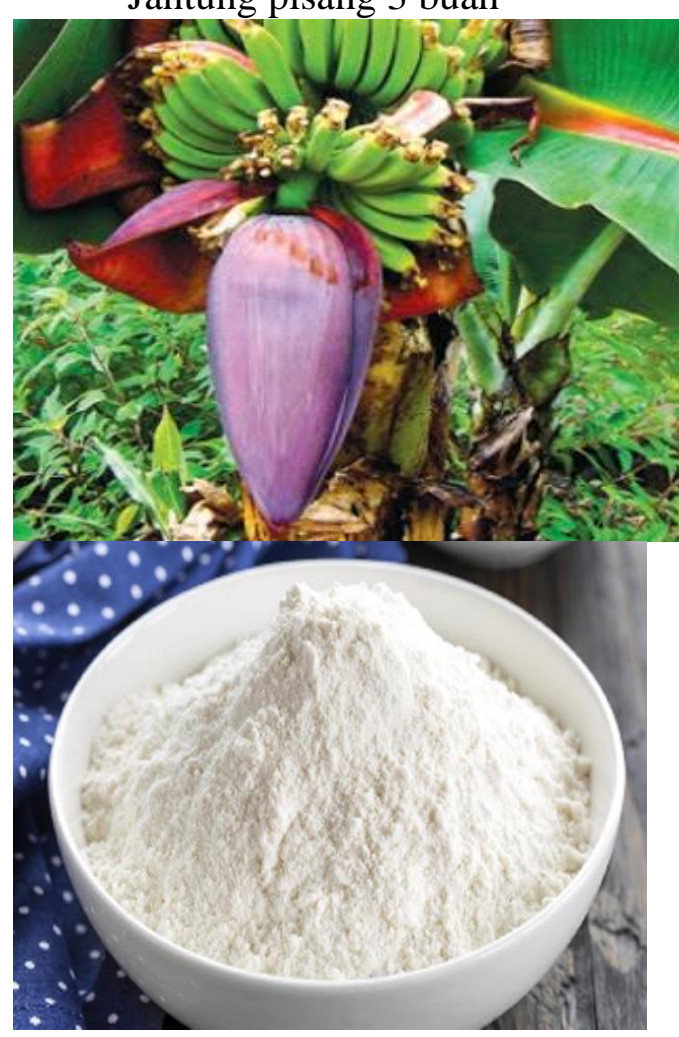

Tepung roti $1 \mathrm{~kg}$
Tepung terigu $1 / 2 \mathrm{~kg}$
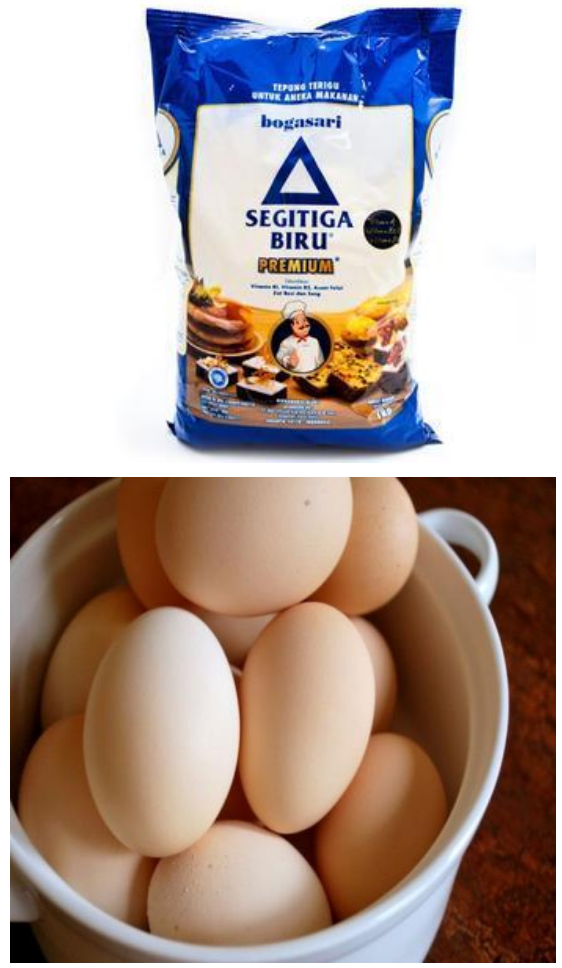

Telur $1 / 2$ kilo
Minyak goreng 1 Liter

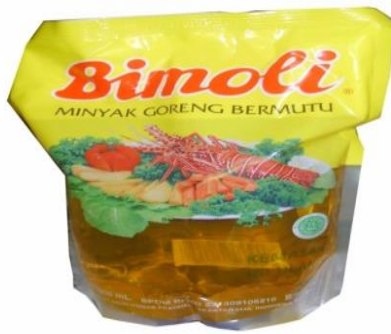

merica bubuk dna garam secukupnya

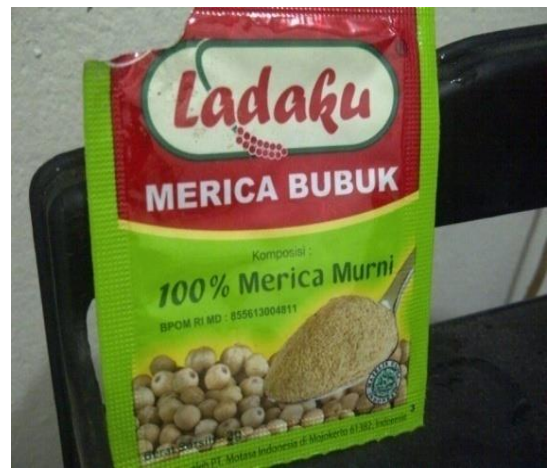




\section{EKOBIS ABDIMAS}

Jurnal Pengabdian Masyarakat

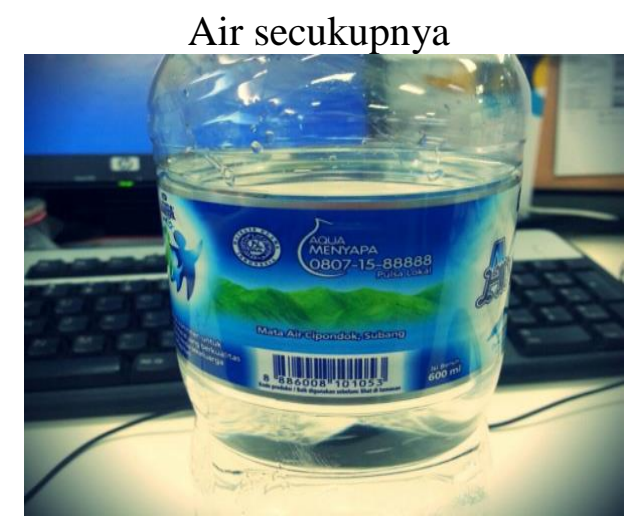

Bawang merah $1 / 4 \mathrm{~kg}$

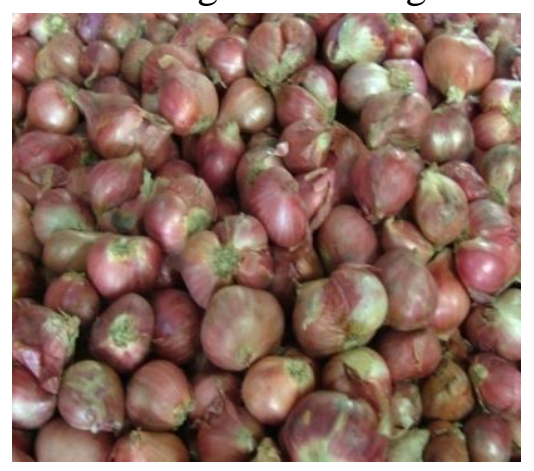

1. Keju 1bungkus

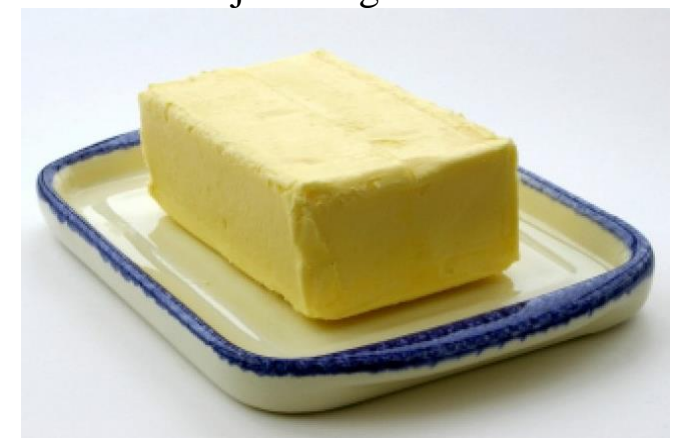

Gula pasir secukupnya

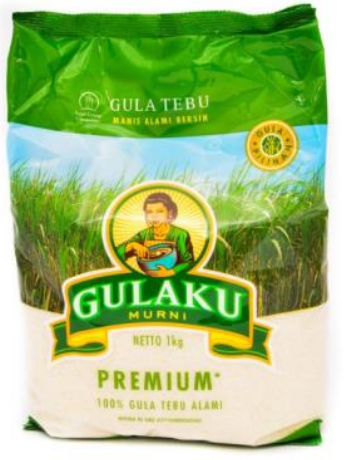

Volume 1, Nomor 2, Desember, 2020

E - ISSN: 2721-9933

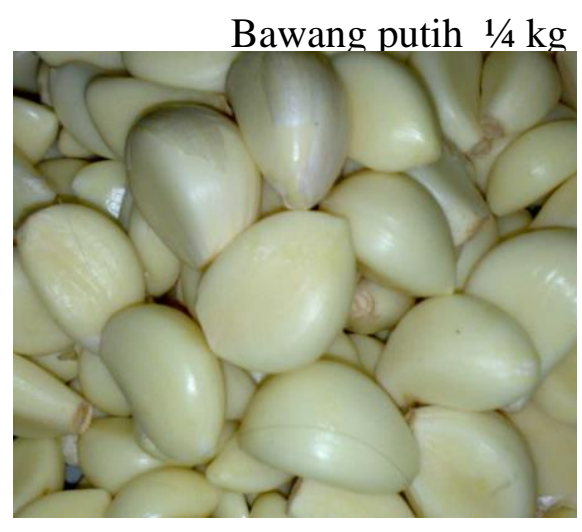

Cabai 1ons

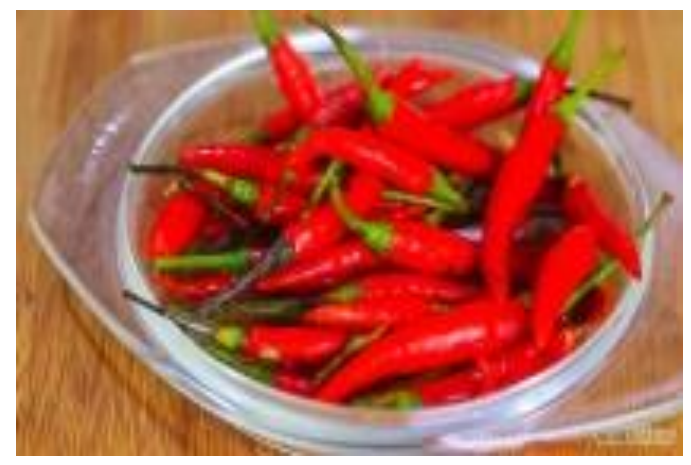

Sosis siap saji 1bungkus

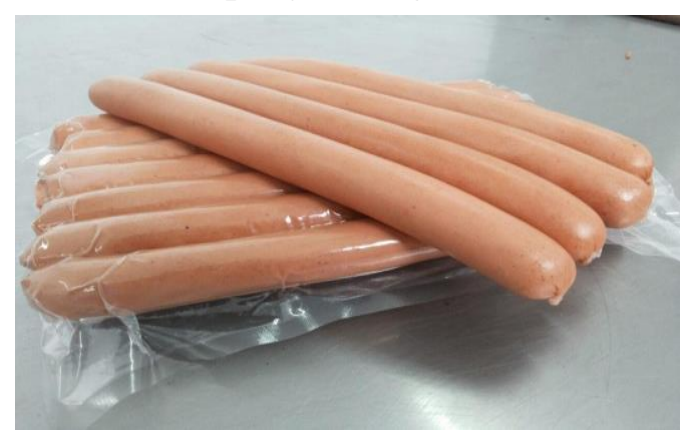

Penyedap rasa secukupnya

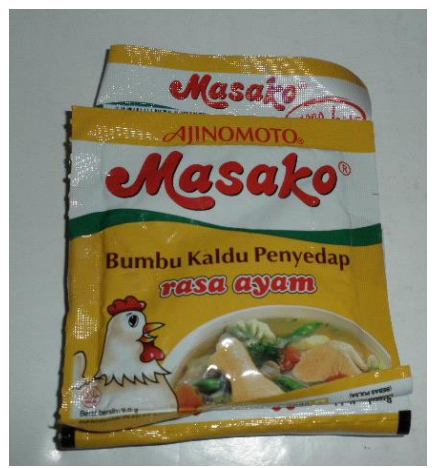


Jurnal Pengabdian Masyarakat

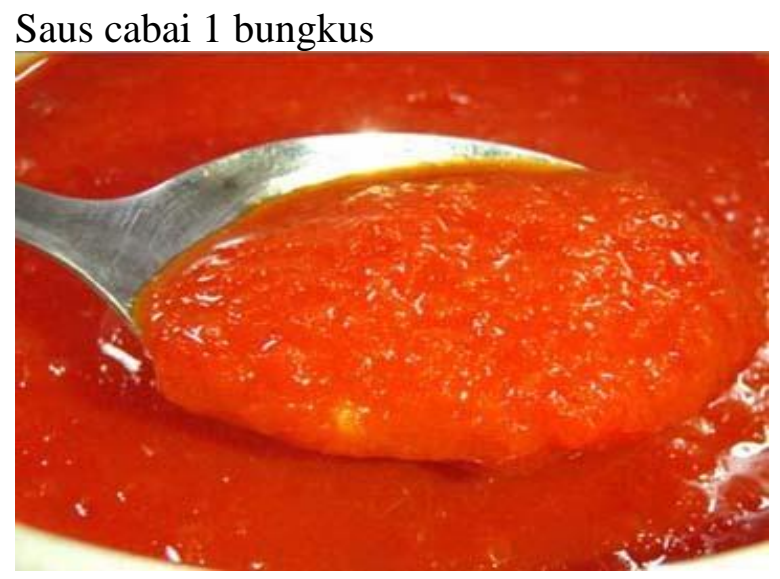

\section{Cara pembuatan atau proses produksi:}

a) Mula-mula jantung pisang di kupas dengan cara dibuang kulit luar yang berwarna merah dan bertekstur kasar hingga ketemu bagian dalam jantung pisang yang berwarna putih kemerahan atau kekuningan.

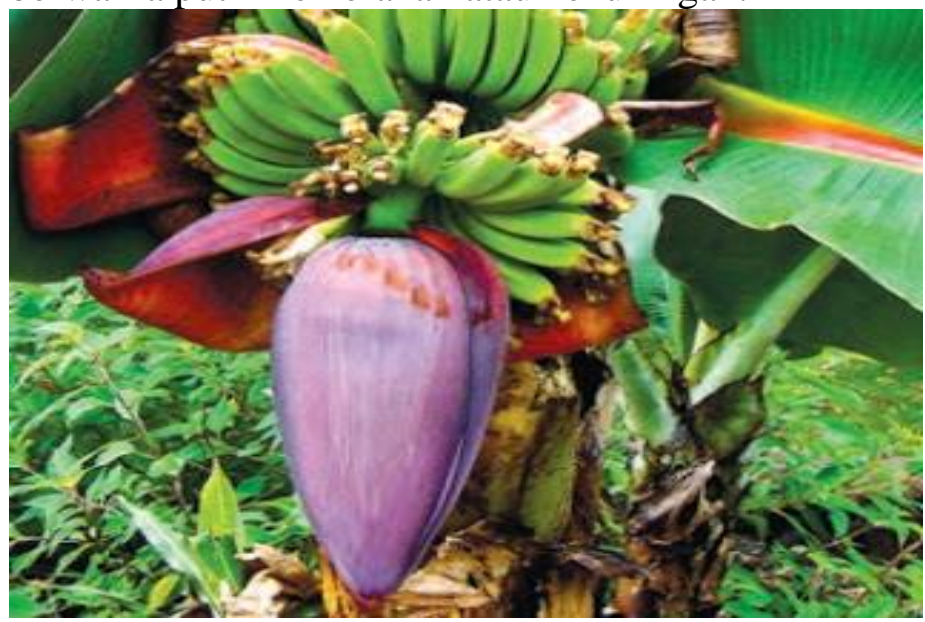

b) Selanjutnya jantung pisang di potong dan di cuci hingga bersih kemudian direbus kedalam air yang mendidih selama 20 menit lalu di angkat, ditiriskan, diamkan selama beberapa menit dan di haluskan menggunakan cobek

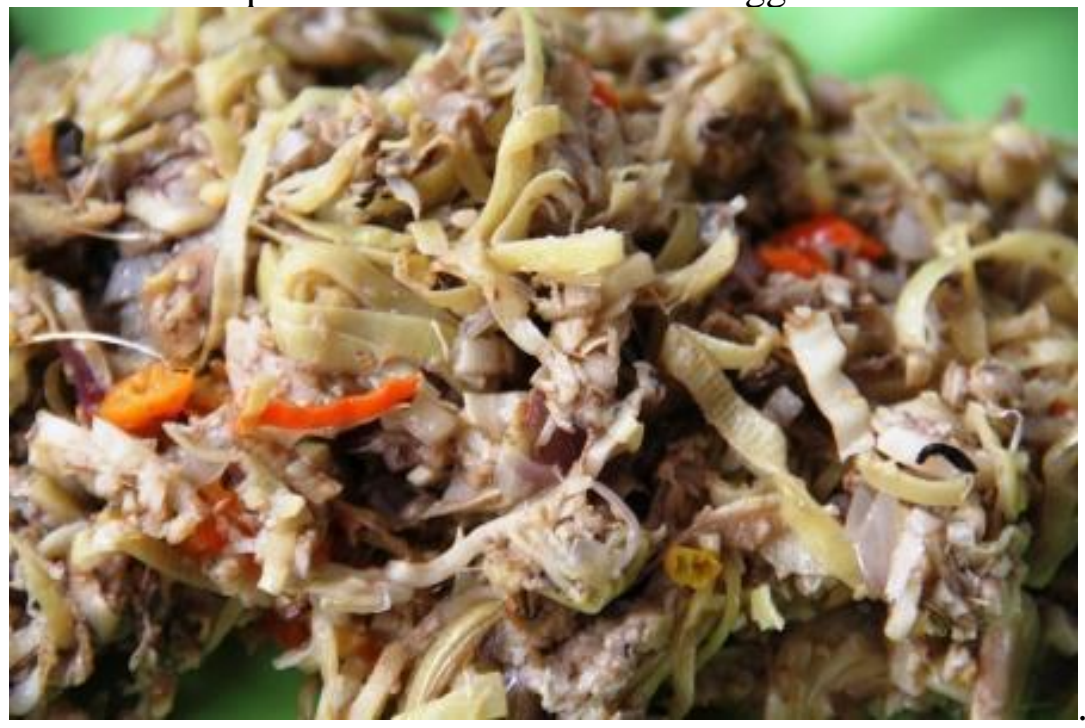


c) Setelah itu pada jantung pisang ditambahkan tepung terigu dengan takaran 4 sendok makan, telur 2 butir, dan bumbu yang sudah dihaluskan yang dibuat dari bawang merah, bawang putih, merica, cabai, garam, gula serta penyedap rasa secukupnya.

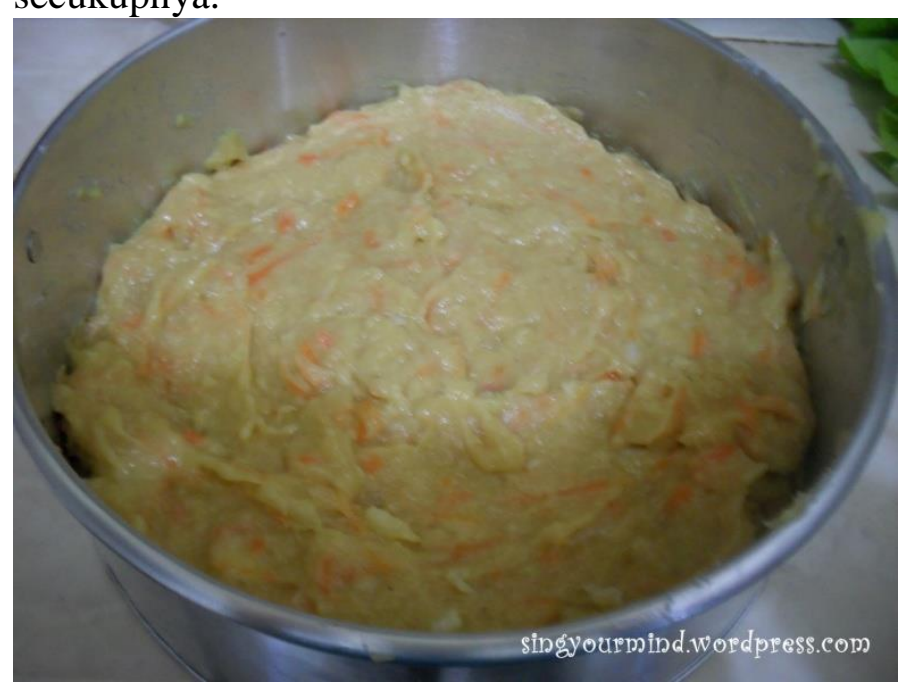

d) Lalu semua bahan tersebut diaduk jadi satu sampai merata hingga menjadi adonan nugget, kemudian adonan nugget tersebut di bentuk menjadi bentuk nugget yang menarik.

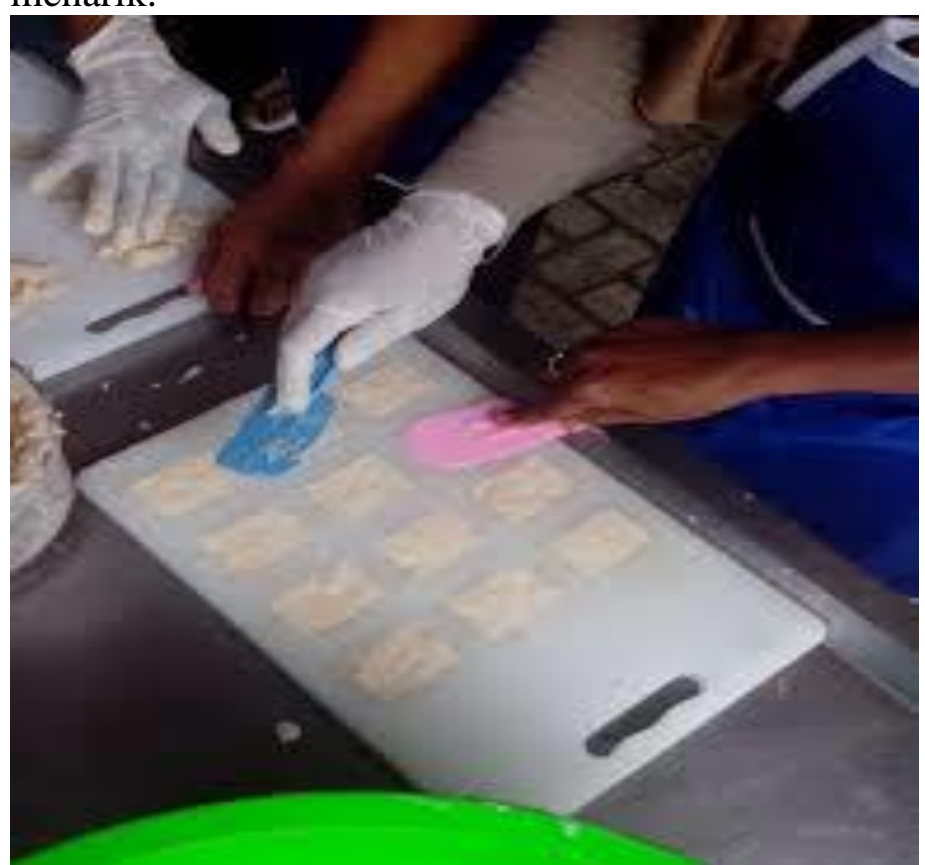

e) Setelah selesai dibentuk, lalu di celupkan kedalam telur yang sudah dikocok dan dicelupkan kedalam tepung roti sambil di bolak-balik satu persatu, kemudian digoreng kedalam minyak yang panas sampai berwarna kecoklatan. 


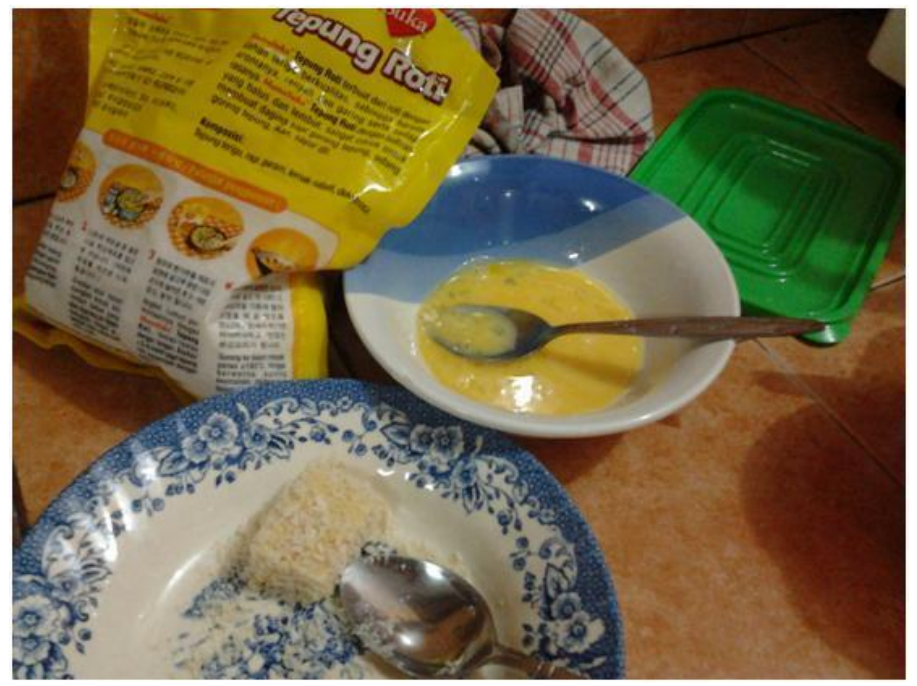

f) Angkat nugget dan tiriskan,kemudian nugget siap untuk disajikan.

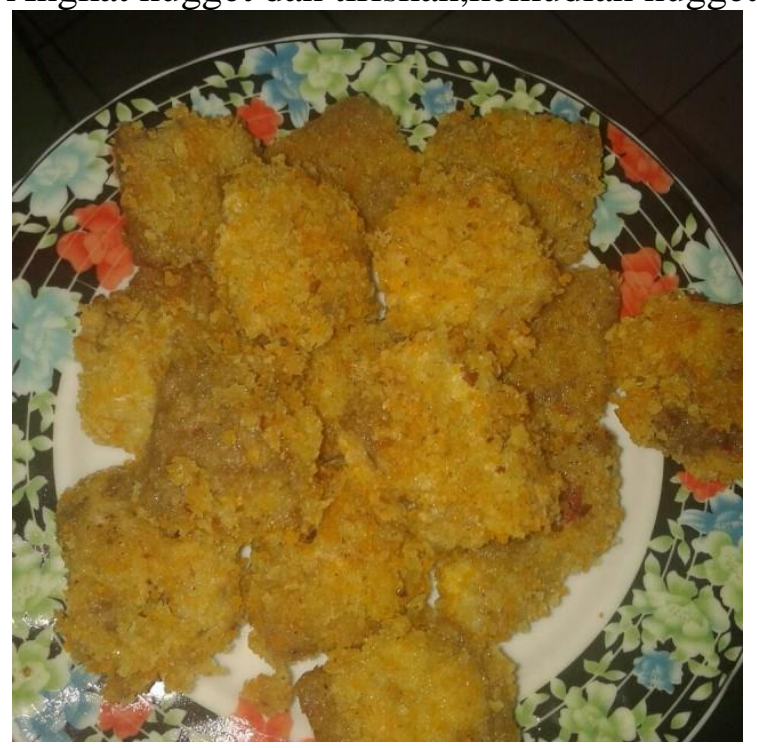

\section{HASIL DAN PEMBAHASAN}

\section{Pengertian Jantung Pisang}

Jantung pisang yang merupakan bunga pisang berwarna merah tua keungguan.

Di bagian dalamnya terdapat bakal buah pisang. Bunga yang satu ini sering disepelekan bahkan diuang karna dianggap menggangupertumbuhan buah pisang, meskipun remeh jantung pisang ini mempunyai sejumlah nutrisi yang bagus untuk merdam sejumlah penyakit. Setiap pohon pisang hanya menghasilkan satu tandan buah pisang yang berasal dari satu jantung atau kelompok bunga pisang. Jantung pisang harus dipotong agart tidak menghambat pertumbuhan buah dan mencegah penyakit pada tanaman pisang. Karenanya jantung pisang sering di anggap limbah yang murah. Meskipun remeh dan murah jantung pisang bernutrisi tinggi. Tiap $25 \mathrm{gr}$ antung pisan, mengandung 31 kalori, 7,1gr karbohidrat, 0,3gram lemak, dan 1,2gram protein.

Jantung pisang merupakan bagian penting dari pohon pisang yang semestinya dapat dioptimalkan penggunaanya sebagai makanan sehat yang dapat dikonsumsi. Karena jantung pisang mengandung vitamin-vitamin yang bermanfaat bagi 
kesehatan manusia seperti vitamin $A$, vitamin $B$, vitamin $\mathrm{C} 1$, selain itu jantung pisang juga mengandung energi, protein, karbohidrat, kalsium, fosfor dan lemak.

Selama ini jantung pisang memang sudah banyak dimanfaatkan untuk pembuatan beberapa makanan seperti abon jantung pisang, tumis jantung pisang dan lain-lain. Namun pada karya ini dibuat suatu inovasi makanan baru yang berbahan dasar dari jantung pisang yaitu nugget jantung pisang karena nugget merupakan jenis makanan praktis yang banyak digemari dan diminati oleh masyarakat modern sekarang. Selain untuk mengoptimalkan penggunaan jantung pisang sebagai sayuran yang sering dibuang karena dianggap limbah dan tidak bisa menghasilkan buah pisang lagi,pembuatan nugget jantung pisang juga untuk meningkatkan nilai jual jantung pisang di pasaran.

\section{Kondisi lingkungan}

Di lingkungan masyarakat yang semakin konsumtif, dapat mempermudah kami dalam membuat produk ini, karena banyak orang-orang yang malas membuat makanan sendiri dan ingin langsung memakan-makanan yang siap saji saja yang praktis dan tidak ribet.Selain itu, di kampus-kampus umumnya menyukai gorengan dan selama ini jenis gorengan yang ada dilingkungan kampus belum ada yang terbuat dari olahan limbah jantung pisang. Oleh karena itu, kami berinisiatif untuk membuka usaha makanan ringan berupa nugget yang berbahan baku limbah jantung pisang yang kaya manfaat.

\section{Sumber Daya dan Bahan Baku}

Dalam pendirian usaha ini, sumber bahan baku utama adalah limbah jantung pisang. Jantung pisang mudah ditemukan dimana saja, apalagi di daerah pedesaan.Jantung pisangdiperoleh dari bunga pohon pisang. Jantung pisang yang bisa di gunakan adalah semua jenis pohon pisang. Dan untuk bumbunya kami racik sendiri dengan memiliki kualitas produk yang bagus dan dijamin higienis.

\section{Lokasi Usaha}

Untuk proses pembuatan produk ini kami membuat di rumah. Untuk lokasi usaha kami akan membuka stand di dalam kampus, di luar wilayah kampus, dan menyewa tempat di luar dengan tempat yang strategis, dekat dengan jalanan yang ramai, dan mudah diketahui oleh banyak orang.agar produk kita degan mudah untuk di kenal di kalangan masyarakat

\section{Peluang Pasar}

Melihat dari banyaknya produk-produk yang kami buat, serta kompetitorkompetitor yang bergerak dibidang usaha yang sama dengan kreatifitas dan keunikannya masing-masing. Hal itu tidak membuat semangat kami menurun dalam berkreasi dan berinovasi. Kami menyiasatiproduk yang kami buat dengan inovasi yang berbeda dari produk-produk yang sudah ada. Yaitu, dengan inovasi rasa yang lebih enak dari rasa yang biasa sampai rasa yang begitu pedas, harga yang ekonomis, dan yang paling penting produk yang kami buat dijamin higienistanpa memakai bahan pengawet atau bahan-bahan yang mengandung kadar kimia yang tinggi serta dapat menyembuhkan penyakit kolestrol dan aman dikonsumsi bagi yang sedang menjalani program diet karena mengandung lemak yang sedikit. Dengan ini, kami yakin produk yang kami miliki mampu bersaing dan laku dipasaran

\section{Strategi Pemasaran yang diharapkan :}

a. Kenali Pelanggan. Kami lebih mengutamakan apa yang diinginkan dan disukai oleh para pelanggan. 
b. Melakukan Promosi Produk. Promosi yang akan kita gunakan dari mulut ke mulut dan juga melalui media social seperti facebook, bbm, twitter, blogger, online shop dan sebagainya.

c. Menentukan dan Memilih Lokasi yang Strategis. Memilih dan menentukan lokasi yang strategis, yang mudah dikenali dan diketahui keberadaan tempat jualan seperti di dekat jalan, di wilayah kampus atau di depan wilayah kampus, dan menyewa tempat.

\section{MANFAAT DAN DAMPAK KEGIATAN}

1. Bagi pemilik usaha memberikan kesempatan untuk membuka usaha dan sebagai sumber pendapatan dan menjadi sarana untuk menuangkan kreatifitas dalam bentuk mengola bahan baku yang di anggap masyarakat bisa-biasa saja menjadi bahan baku yang lebih bermanfaat dan bernilai ekonomi tinggi, menjadi sarana yang tepat untuk belajar berbisnis dan meningkatkan kemampuan kewirausahaan.

2. Bagi pemerintah mengurangi jumlah pengganguran lulusan perguruan tinggi,meningkatkan ketahanan perekonomian di kota lamongan dan meningkatkan hasil cipta karya bahan olahan makanan dari bahan baku lokal serta mendorong pemerintah untun menciptakan produk makanan lokal tertentu dari bahan baku lainnya

3. Bagi masyarakat merangsang kreatifitas masyarakat untuk berwirausaha,membuka lapangan pekerjaan bagi masyarakat dan menyediakan cemilan yang sehat yang memiliki nilai gizi tinggi serta meningkatkan perekonomian masyarakat sehingga terbentuk masyarakat yang mandiri

\section{SIMPULAN}

Naget jantung pisang di harapkan menjadi sebuah produk yang memiliki ciri khas tersendiri,naget jantung pisang ini di kembangkan sesuai degan selera masyarakat luas,di mana naget jantung pisang hanya di olah degan rasa original,tetapi degan berbagai rasa yang sesuai degan lidah orang indonesia sehingga akhirnya dapat di terima dan di gemari oleh masyarakat luas. Dengan hadirnya usaha ini di harapkan dapat merangsang kreatifitas masyarakat dalam berwira usaha serta menumbuh kembangkan jiwa kewirausahaan pada masyarakat seiring berjalanya usaha ini kami berharap usaha ini memiliki asar yang luas dan produk kami di kenal masyarakat secara luas, melalui sistem penjualan distributor ke berbagai daerah dan memeperkenalkan produk ini melalui jaringan sosial. Dengan memiliki jaringan pasar yang luas maka di harapkan produk kami dapat degan cepat di kenal masyarakat sebagai hasil karya anak bangsa dan melestarikan makanan lokal yang inovatif serta kreatif.

\section{UCAPAN TERIMAKASIH}

Artikel ini bisa kami selesaikan atas kerjsama semua pihak, untuk itu izinkan kami menghaturkan terimakasih kami kepada:

1. Ibu-ibu PKK RT 01/03, Ngaglik Barat, kelurahan Sukorejo, Kabupaten LAMONGAN

2. Mahasiswa Bimbingan PKM, FE - Unisda Lamongan

3. Rektor Unisda Lamongan beserta civitas Akademika Unisda

4. Serta semua pihak yang ikut serta membantu dalam penyusunan karya ilmiah pengabdian masyarakat ini. 


\section{DAFTAR PUSTAKA}

Enny Zuhni Khayati. (1997). Ilmu kewirausahawan. Yogyakarta: FPTK IKIP Yogyakarta.

M. Hasanuddin, Widjiyati, dkk. (2001). Penerimaan Penerapan Zat Warna Alam dan Kombinasinya pada Produk makanan nugget jantung pisang. Laporan Penelitian. Yogyakarta: BBKB.

Hasan, Masrur. 1994. Sejarah nugget (dokumen pribadi).

Musman Asti, Ambar B. Arini. 2011. Makaanan Warisan Adiluhung Nusantara. Yogyakarta: G-Media.

Mifzal Abiyu. 2012. Mengenal Ragam makanan nusantara Jogjakarta: Javalitera.

Soerjanto. 1982. Sejarah Perkembangan makanan. Yogyakarta: Balai Besar Penelitian dan pengembangan industrri makanan inivatif.

Yuliati Dewi. 2009. Mengungkap Sejarah dnuggetjntung pisang. Semarang: Badan Penerbit Universitas Diponegoro.

Fitri Yaning Tyas. “Analisis jantung pisang”. e-Journal Ilmu Komunikasi.Volume 1, Nomor 04,

Gde Yosef Tj. Filsafat sebagai Dasar Kajian dalam Penerapan Makanan berbahan jantung pisang. Jurnal ilmiah "PRABANGKARA". Volume 14 Nomor 17 Tahun 2011.ISSN 1412-0380. Hal 73-81.Himmatul Hanifa, Yuhri Inang Prihatina. "Makanan". e-Journal Edisi Yudisium. Volume 02 Nomor 01, Februari 2013.6571. 